\title{
A Study on Socio-Economic Profile of Migratory Sheep Farmers in Narayanapet District of Telangana State
}

\author{
G. Nijanand ${ }^{1}$, N. Rajanna ${ }^{2 *}$, R. Suresh ${ }^{3}$, D. Sakaram ${ }^{4}$ and M. Sreenivasa Reddy ${ }^{5}$ \\ ${ }^{1}$ Veterinary Assistant Surgeon, PVC, Tandur, Vikarabad District, Telangana, India \\ ${ }^{2}$ Department of LPM, College of Veterinary Science, PVNRTVU, Mamnoor, Warangal (U), Telangana State, India \\ ${ }^{3}$ Department of ILFC, College of Veterinary Science, PVNRTVU, Rajendranagar, Hyderabad, Telangana State, India \\ ${ }^{4}$ Department of AGB, College of Veterinary Science, PVNRTVU, Rajendranagar, Hyderabad, Telangana State, India \\ ${ }^{5}$ Department of V\&AH Extension, College of Veterinary Science, PVNRTVU, Rajendranagar, Hyderabad, Telangana State, India
}

*Corresponding author: rajlpm2001@gmail.com (ORCID ID: 0000-0002-6512-7753)

Paper No. 951

Received: 14-04-2021

Revised: 23-07-2021

Accepted: 27-08-2021

\begin{abstract}
A study was conducted to analyze the socio-economic profile of the migratory sheep farmers in the Narayanapet district of Telangana state. Data were collected from 125 migratory sheep farmers by following the multistage random sampling techniques through personal interviews. The study revealed that the majority (67.2. \%) of the shepherds belonged to the middle age group and the mean age of the sheep farmers was $38.66 \pm 11.72$ years. A majority $(77.60 \%)$ of the sheep farmers were illiterates, and only 22.40 percent of farmers were literates. Shepherds' average sheep farming experience was $23.65 \pm 12.58$ years, and the average family size was $4.67 \pm 1.67$. The nuclear family $(71.20 \%)$ was the most prevalent type in the three flock sizes of Narayanpet district. All the shepherds (100\%) among three categories of flocks in the surveyed area belonged to the backward caste (BC) only. Among the shepherds, the majority $(93.6 \%)$ of the sheep farmers had sheep rearing as a significant occupation. The average annual income of the shepherds was ₹ $85760 \pm 55808.1$ - and 80.00 percent of shepherds had a median annual income of ₹ 29952/- to ₹ 141568.1/-. A significant ( $\mathrm{P}<0.01)$ relationship between the annual income of shepherds and the category of flock size was observed amongst the three flock categories. It was noticed that 57.60 percent and 42.40 percent of the shepherds were residing in pucca and kutcha houses, respectively, during their non-migratory period

\section{HIGHLIGHTS}

( Migratory sheep farming is mostly practiced by sheep farmers in Telangana.

( For sustainability of migratory sheep farming and formulation of specific policies, study on the socio-economic profile is essential.

(0 The younger generation from the shepherds' communities are diverting towards other vocations due to hardships involved in migratory sheep farming.
\end{abstract}

Keywords: Socio-economic profile, sheep farmers, igratory production system

Sheep is an important livestock species of India. They contribute greatly to the agrarian economy, especially in the arid, semi-arid, and mountainous areas where crop and dairy farming are not economical. According to the $20^{\text {th }}$ Livestock Census (2019) the sheep population in India is 74.26 million and contributes 13.87 percent of the total livestock population. India ranks third in the world and contributes 6.8 percent of the world's sheep population, and contributes to $4.9 \%$ of total meat production in the country. Sheep are usually

\footnotetext{
How to cite this article: Nijanand, G., Rajanna, N., Suresh, R., Sakaram D. and Reddy, M.S. 2021. A Study on Socio-Economic Profile of Migratory Sheep Farmers in Narayanapet District of Telangana State. Int. J. Ag. Env. Biotech., 14(04): 631-634.

Source of Support: None; Conflict of Interest: None (2) 8
} 
kept under extensive management and reared on natural vegetation. Still, due to the shrinkage of grazing land, the maintenance of flocks under an extensive system is threatened. In the extensive management system, the animals are reared on poor and degraded grazing lands resulting in low production and reproduction. This scenario forces the sheep flock owners to migrate with their flocks for sustenance. Seasonal migration from their native place with sufficient water and grass in the field is an essential feature of sheep management in our country, including Telangana state. The migratory sheep flocks follow some well-established migration routes for about 5 to 6 months in a year in search of grazing and water resources. The sheep reared in this traditional way lacks the minimum necessities required for proper development, and sheep flocks are prone to diseases that lead to high mortality. Sheep production is an important tool to improve the socio-economic status of rural people; hence, a study on the socio-economic profile of migratory sheep farmers in Narayanpet district was carried out to formulate the future policies for sheep development in migratory routes.

\section{MATERIALS AND METHODS}

The study was conducted in the Narayanpet district of Telangana state purposively as the sheep rearing is mainly carried out by seasonal migration and having the highest sheep population in the state. This district is located at $16.746688^{\circ} \mathrm{N}$ and 77.495815 ${ }^{\circ} \mathrm{E}$. Narayanpet has a semi-arid climate and receives an average annual rainfall of $534.5 \mathrm{~mm}$. Multistage random sampling technique was adopted in selecting migratory sheep farmers. In the first stage, five mandals were selected from the district to have the highest sheep population. In the second stage, five villages from each mandal were selected. In the third stage, five migratory shepherds from each of the selected villages were selected random. The total sample size constituted 125 farmers for the study as a whole.

The data was collected from the respondents using a pretested and well-structured interview schedule personally by the researcher. The data collected during the period of study were scrutinized and tabulated into frequency, percentages, arithmetic mean, standard deviation, standard error, and analysis of variance following the methods suggested by Snedecor and Cochran (1994) while the significant differences between parameters and frequencies were analyzed by Chi-square test using SPSS, version 22.0.1 (Statistical package for social sciences). The information obtained was analyzed, and interpreted.

\section{RESULTS AND DISCUSSION}

The socio-economic profile of the sheep farmers is presented in Table 1.

\section{Age}

A majority (67.2. \%) of the flock owners belonged to the middle age group, followed by old age (16.8.\%) and young age group (16.0. \%) in the study area. The mean age of shepherds was $38.66 \pm 11.72$ years. Young people from the study area choose new vocations rather than occupations like sheep farming due to hardship faced by the migratory people in remote areas besides to urbanization and industrialization in the study area. Similar results were reported by Rajanna et al. (2013), Nisha et al. (2016), and Kantwa and Mohanty (2021).

\section{Education}

Literacy level plays a key role in the adoption of new technologies in sheep rearing. From the Table, it was found that the majority $(77.60 \%)$ of the shepherds were illiterates, and only 22.40 percent of farmers were literates. This might be due to that the farmers have been practicing sheep farming through generations and have shown less interest in education, and the migratory production system itself provides them less opportunity to obtain education. The government and the concerned authorities should plan to improve their educational status, which may improve both their social and livelihood status in society (Rajanna 2011; Sundaramoorthy et al. 2021).

\section{Experience}

On perusal of Table, it was observed that the majority $(64 \%)$ of the sheep farmers had medium experience $(64.0 \%)$ in sheep rearing followed by a low level of experience (18.4\%) and a high level of sheep farming experience $(17.6 \%)$ in the study area. The average sheep farming experience of shepherds was $23.65 \pm 12.58$ years. Shaik et al. (2017) 
Table 1: Socio-economic profile of migratory sheep farmers

\begin{tabular}{|c|c|c|c|c|c|c|}
\hline \multirow{2}{*}{ S1. No. } & \multirow{2}{*}{ Parameter } & \multicolumn{4}{|c|}{ Flock size } & \multirow{2}{*}{$\begin{array}{l}\text { Chi-square } \\
\text { value }\end{array}$} \\
\hline & & Small $(n=16)$ & Medium $(n=90)$ & Large $(n=19)$ & Total $(n=125)$ & \\
\hline \multirow[t]{4}{*}{1} & Age (Years) & & & & & \\
\hline & Low $(<27)$ & $2(12.5)$ & $16(17.78)$ & $2(10.53)$ & $20(16.0)$ & \multirow{3}{*}{$1.260^{\mathrm{ns}}$} \\
\hline & Medium (27-50) & $12(75.0)$ & $58(64.44)$ & $14(73.68)$ & $84(67.2)$ & \\
\hline & $\operatorname{High}(>50)$ & $2(12.5)$ & $16(17.78)$ & $3(15.79)$ & $21(16.8)$ & \\
\hline 2 & Education & & & & & \\
\hline \multirow[t]{4}{*}{3} & Experience & & & & & \\
\hline & Low $(<11)$ & $7(43.75)$ & $15(16.67)$ & $1(5.26)$ & $23(18.4)$ & \multirow{3}{*}{$9.221^{\mathrm{ns}}$} \\
\hline & Medium (11-36) & $7(43.75)$ & $59(65.56)$ & $14(73.68)$ & $80(64.0)$ & \\
\hline & High $(>36)$ & $2(12.5)$ & $16(17.78)$ & $4(21.05)$ & $22(17.6)$ & \\
\hline 4 & Family type & & & & & \\
\hline \multirow{3}{*}{5} & Low & $3(18.75)$ & $9(10.0)$ & $0(0.0)$ & $12(9.6)$ & \multirow{3}{*}{$4.368^{\mathrm{ns}}$} \\
\hline & Medium & $9(56.25)$ & $60(67.7)$ & $15(78.9)$ & $84(67.2)$ & \\
\hline & High & $4(25.0)$ & $21(23.3)$ & $4(21.1)$ & $29(23.2)$ & \\
\hline \multirow[t]{4}{*}{6} & Annual Income & & & & & \\
\hline & Low $(<₹ 29952 /-)$ & $3(18.75)$ & $8(8.9)$ & $0(0.0)$ & $11(8.8)$ & \multirow{3}{*}{$32.146^{* *}$} \\
\hline & Medium (₹ 29952 to ₹ 141568) & $13(81.25)$ & $77(85.6)$ & $10(52.6)$ & $100(80.0)$ & \\
\hline & High $(>₹ 141568.1)$ & $0(0.00)$ & $5(5.5)$ & $9(47.4)$ & $14(11.2)$ & \\
\hline \multirow[t]{3}{*}{7} & Sheep farmers residence type & & & & & \\
\hline & Kutcha & $6(37.5)$ & $43(47.80)$ & $4(21.05)$ & $53(42.40)$ & \multirow{2}{*}{$5.442^{\mathrm{ns}}$} \\
\hline & Pucca & $10(62.5)$ & $47(52.20)$ & $15(78.95)$ & $72(57.60)$ & \\
\hline \multirow{4}{*}{9} & Small (2.5-5 Acres) & $5(31.25)$ & $33(36.67)$ & $4(21.05)$ & $42(33.6)$ & \multirow{3}{*}{$4.26^{\mathrm{ns}}$} \\
\hline & Marginal (<2.5 Acres) & $2(12.5)$ & $23(25.56)$ & $6(31.58)$ & $31(24.8)$ & \\
\hline & Landless & $1(6.25)$ & $6(6.67)$ & $1(5.26)$ & $8(6.4)$ & \\
\hline & Mean \pm SE of land size & $1.75 \pm 0.19$ & $2.01 \pm 0.10$ & $2.36 \pm 0.19$ & $2.02 \pm 0.08$ & \\
\hline
\end{tabular}

Figures in the parentheses indicate the percent to the total; $n s-$ Not significant, ${ }^{* *}$ Significant $(P<0.01)$.

and Sundaramoorthy et al. (2021) reported that the majority of the farmers had medium farming experience.

\section{Family Type and Size}

The majority of the shepherds' families were of nuclear type $(71.20 \%)$, followed by joint type $(28.80 \%)$ in the study area. This is might be due to the transformation of the social structure from the joint family to the nuclear family on account of urbanization, industrialization, increased cost of living, etc. Rajanna et al. (2013), and Sundaramoorthy et al. (2021) observed a similar trend in their studies.
The average family size in the present study was $4.67 \pm 1.67$, and the majority $(67.2 \%)$ of the sheep farmers belonged to medium family size, followed by high (23.2\%) and low (9.6\%). Medium family size was helpful during the migration period.

\section{Annual Income}

The study on annual income of migratory sheep flock owners revealed that the majority of the shepherds $(80.0 \%)$ had medium annual income with ₹ $29952 /$ - to ₹ $141568.1 /$, followed by high (11.2\%) with above ₹ $141568.1 /$ - and low income (8.8\%) with less than ₹ 29952/- in the study area. The average 
annual income of shepherds in the study area was ₹ $85760 \pm 55808.1 /-$. The Chi-square test revealed a significant $(\mathrm{P}<0.01)$ relationship between the annual income of shepherds and the category of flock size. This was due to their flock size, and sheep were the main source of income to the migratory shepherds in the study area (Rajanna et al. 2012a and Kantwa and Mohanty 2021).

\section{Sheep Farmer's House Type}

It was noticed that 57.60 percent and 42.40 percent of the shepherds were residing in pucca and kutcha houses, respectively, during their non-migratory period in the study area. There is no significant difference between house type and flock size. These findings were in consonance with the findings of Lavanya et al. (2016) reported that the majority of shepherds $(88.46 \%)$ possessed pucca houses made of RCC and stone structure followed by 11.54 percent kutcha house.

\section{Occupation}

From the table, it was found that the majority $(93.6 \%)$ of the shepherds had sheep rearing as a major occupation, and only 6.4 percent had both sheep rearing and agriculture as an occupation in the study area. Sheep farming is a traditional occupation, and this occupation is practiced from generation to generation (Choudary et al. 2013 and Sirshat et al. 2019).

\section{Land Holding}

It was observed that about 35.2 percent of flock owners belonged to the large farmer's category, followed by 33.6 percent being small farmers and 24.8 percent being marginal, and 6.4 percent farmers were a landless category in the study area. Though the migratory sheep flock owners have the land, they do not depend on agriculture, as their main occupation is sheep rearing. The reduction in the size of land holdings is attributed to the fragmentation of agricultural lands to the descendants of the farmers, sale of land for want of money, failure of seasonal rain, conversion of agricultural lands into residential and industrial plots, which has led to an overall reduction of agricultural operations (Singaravadivelan et al. 2019).

\section{ACKNOWLEDGEMENTS}

The authors are highly thankful to the authorities of P.V.Narsimha Rao Telangana Veterinary University (PVNRTVU) for according the permission to carry out the work by the researcher.

\section{REFERENCES}

Choudary, P.V., Ekambaram, B., Prakash, M.G. and Rajanna, N. 2013. Socio-economic characteristics and marketing attributes of Macherla Brown sheep farmers. Indian J. Anim. Prod. Mgmt., 29: 1-2.

Kantwa, S.C., Mohanty, T.K., Patbhanda, T.K., Layek, S.S. and Kumaresan, A. 2017. Diseases incidence and mortality pattern of migratory sheep flocks in Marwar region of Rajasthan. Int. J. Curr. Microbiol. Appl. Sci., 6: 684-690.

Shaik, M., Subrahmanyeswari, B. and Sharma, G.R.K. 2017. Analyzing the socio-personal, economic profile and preparedness of sheep farmers. Int. J. Environ. Sci. Technol., 6(3): 1641-1649.

Nisha, P.R., Mohammed Safiullah, A., Sasikala, V. and Saravanan, K.P. 2016. Migratory sheep rearing in Thanjavur district of Tamil Nadu. Indian J. Small Ruminants., 22(1): 134-136.

Rajanna, N. 2011. Field Evaluation of Management Practices and Performance of Sheep in Telangana region of Andhra Pradesh. Ph.D. Thesis submitted to Sri Venkateswara Veterinary University, Tirupati.

Rajanna, N., Mahender, M., Thammiraju, D., Raghunadan, T., Nagalakshmi, D. and Sreenivasa Rao, D. 2012. Socioeconomic status and flock management practices of sheep farmers in Telangana region of Andhra Pradesh. Vet. Res., 5(2): $37-40$

Rajanna, N., Mahendar, M. and Ramana, K.V. 2013. A study on migration pattern of Sheep flocks in Telangana region of Andhra Pradesh. J. Res. ANGRAU., 41(1): 42-46.

Shirsat, S.G., Kolhe, S.R, Nande, M.P., Khanvilkar, A.V. and Shende, T.C. 2019. Pattern of migration followed by migratory shepherds of western Maharashtra. Int. J. Agric. Sci., 11(7): 8242-824.

Singaravadivelan, A., Kumaravelu, N., Vijaykumar, P. and Sivakumar, T. 2019. An economic analysis of migratory sheep production system in Tamil Nadu. J. Anim. Health Prod., 7(2): 58-64.

Snedecor, G.W. and Cochran, G. 1994. Statistical methods $\left(8^{\text {th }}\right.$ Ed) The lowa State University Press, OWA, USA .

Sundaramoorthy, M., Kumaravelu, N., Thanga Thamilvanan., Serma Saravana Pandian, A. and Divyalakshmi, D. 2021. Pattanamadu sheep farming in the breeding tract: The socio-economic dimensions. J. Entomol. Zool. Stud., 9(1): 1490-1493. 